\title{
Prospective Influence of Phytotherapy on Resistant Bacterial Tonsillitis
}

\author{
Amad A. El Marghani ${ }^{1 *}$, Khaled A. Algariri ${ }^{2}$ and P.M. Ridzuan ${ }^{3}$ \\ ${ }^{1}$ Department of Biomedicine, ${ }^{2}$ Department of Biochemistry, ${ }^{3}$ Department of Microbiology, International \\ Medical School, Management and Science University (MSU), University Drive, off Persiaran Olahraga, Section \\ 13, 40100 Shah Alam, Selangor Darul Ehsan, Malaysia.
}

\begin{abstract}
The emergence and evolution of superbugs is among the greatest challenges to public health worldwide recently. Bacterial resistance to antibiotics considered as one of greatest hits of this century. There are different antibiotic resistant strains that range for infection from mild to severe cases and tonsillitis is one among of many bacterial diseases that have high incidence globally. Half of tonsillitis cases are bacterial and those mainly caused by group-A beta-hemolytic streptococci (GABHS) bacteria which had developed its resistance against commonly used antibiotics, mainly penicillin and macrolids. Currently, however, there are considerable attempts to tackle the issue despite they are still far away from promised settlement. Focusing on testing and evaluating of herbal therapies will be of great value in finding of potent alternative medicine to face resistant bacterial infections and to provide sufficient therapeutic agent to disband the problem. Hence the necessity to develop novel therapeutics to replace conventional antibiotics will likely play a key role to fix the issue. This article concentrate on review of ineffective antibiotic therapy including some of its impacts and describes possibility to use Saussurea Iappa (S. Lappa) plant as an effective herbal plant to treat resistant bacterial acute tonsillitis cases.
\end{abstract}

Keywords: Bacterial resistance, $\beta$-hemolytic streptococci bacteria, Broad spectrum activity, Saussurea lappa, Tonsillitis.

\footnotetext{
*Correspondence: amadalmarghani@gmail.com; 014-7352079
}

(Received: 11 November 2018; accepted: 20 December 2018)

Citation: Amad A. El Marghani, Khaled A. Algariri and P. M. Ridzuan, Prospective Influence of Phytotherapy on Resistant Bacterial Tonsillitis, J Pure App/ Microbiol., 2019; 13(1):167-178 doi: 10.22207/JPAM.13.1.17

(c) The Author(s) 2019. Open Access. This article is distributed under the terms of the Creative Commons Attribution 4.0 International License which permits unrestricted use, sharing, distribution, and reproduction in any medium, provided you give appropriate credit to the original author(s) and the source, provide a link to the Creative Commons license, and indicate if changes were made. 


\section{INTRODUCTION}

Thousands years ago, the human being exposed to many infectious diseases ranged from amiable to lethal cases. He struggled to face, cure such diseases and to find specific treatments. Bacterial infections play significant role among other types of infectious diseases. Bacterial infections are one of the most dangerous infections that threaten the existence and continuity of life. Despite the discovery and manufacturing of effective antibiotics to tackle this menace, bacteria have digged its way to live and develop resistance against these treatments and transformed into new mutant resistant strains. Tonsillitis is one of the critical bacterial infections that hits globally, it affects throat and can be viral or bacterial ${ }^{1}$. Thirty percent of cases caused by group-A beta-hemolytic streptococci (GABHS) bacteria ${ }^{2}$. Generally, treatment depends on causative agent and course of disease accordingly, because that tonsillitis may occur in the form of chronic or acute condition. However acute bacterial cases routinely treated by broad spectrum antibiotics and symptomatic therapy (by non-steroidal anti-inflammatory drugs [NSAIDs]), a rationale that deduce we need a combination of multiple treatments to get rid of tonsillitis.

Long time ago, antibiotics were used to treat many different bacterial infections and their discovery printed a foot on a map of our medicine. Eventually, with their uncontrolled widespread usage, the bacteria carpe diem and the condition leads to developed drug resistance to these organisms ${ }^{3}$. Currently, our health vulnerable to hazards of antibiotics resistance. First of all, the end fate of failure of treatment. Then its peripheral impacts, antibiotic resistance increases healthcare costs due to ineffective treatment courses, causes people to stay in hospital longer, results in treatment failures and sometimes death ${ }^{4}$. Therefore, rigorous research activities are being carried out around the globe to develop alternative methods for treatment of infectious diseases caused by multi-drug resistant (MDR) bacteria, these include using of bacteriophages, phage lytic enzymes, bacteriocins, antimicrobial peptides or herbal medicines. Traditional herbal medicine by medicinal herbs seems to be a good option for this problem.

From early human life, traditional herbal medicine based on medicinal plants application according to experience and practice through trial and error method ${ }^{5}$. Medicinal plants used today were known to people of ancient cultures all over the world long time ago and their application continuous to grow due to experienced potency without undesired effects. For instance, due to their anti-inflammatory and anti-septic properties they were used to treat many inflammations ${ }^{6}$. Saussurea lappa (S. lappa) is one of the reported plants which used to treat many inflammatory conditions like sickness of women after delivery?. This article will focus on treatment of resistance problem in tonsillitis cases and possibility to apply S. lappa for its treatment instead of using conventional antibiotics.

\section{LITERATURE REVIEW}

Our health is endangered by arising of superbugs, those bacteria which developed a powerful resistance to utmost already developed antibiotics. Many reports from dependable foundations (e.g. World Health Organization [WHO] and Centers of Disease Control and prevention $[C D C]$ ) revealed the outbreak of problem and disclosed predictable riskiness that threaten our life ${ }^{8}$. Review of related previous literature uncovers the horrible image of bacterial resistance issue and the importance of herbal medicine to stand up against the problem. For that this paper centralized upon finding proper herbal remedy to overcome on resistant bacteria at least in case of tonsillitis infection.

\section{Background of Tonsillitis}

Tonsillitis is defined as inflammation of palatine tonsils, which is infection and inflammation of tonsils (glandular tissue on either side of the back of throat) ${ }^{2}$. Our tonsils are considered as one of the important part in our primary immune system ${ }^{12}$. Their inflammation is a complex pathophysiological defense reaction of vascular tissues in a response to harmful stimuli that can be distinguished by certain symptoms and signs ${ }^{9}$. Its symptoms involve sore throat with difficulty swallowing (dysphagia), hoarse or muffled voice, localized pain especially with swallowing process, fever, loss of appetite, general unwell, drooling, swollen associated lymph nodes, adenopathies, glossitis and palatine petechiae may be included, in advanced cases, abdominal pain 
and vomiting may be reported ${ }^{2}$. Signs embrace congestion of pharyngeal mucosa, sometimes with or without purulent exudates, ulcers, blisters and swollen erythematic tonsils covered by white or yellow pustules².

As many inflammatory conditions, tonsillitis appears as acute, chronic or recurrent condition. Recurrent attacks characterized by hypertrophic tonsils' glandular tissue followed by difficulty in swallowing and breathing, persistent pain and general malaise, all of these in turn affect daily life from many aspects. Acute condition may progress to recurrent one that needed to be treated surgically by tonsillectomy ${ }^{10}$.

Acute tonsillitis may occur due to viral or bacterial infection and just slight diagnostic differences between them can be noticed by clinical observation, the matter that necessitate clinicians to apply cultural swabs for lab diagnostics. Many reports show that there is misdiagnosis of tonsil cancer too, in which reported cases were diagnosed by general practitioners as tonsillitis cases then after long time of resistance of disease to treatment by antibiotics they suggested by specialists they are cancer cases. A study by Dubai et al., (2012) aimed to reveal importance of education of related knowledge among students, the matter that this condition needs intensive knowledge and experience ${ }^{11}$.

Bacterial etiology characterized by pus formation, and most of cases gets infectious bacteria via mouth, while viral cases characterized by hemorrhagic oozing and infectious virus directed from nose route. Furthermore, viral cases of tonsillitis have short attacks and mostly resolve spontaneously. Tonsillitis causative agents include Streptococcus pyogenes, Staphylococcus aureus, Corynbacteriun diphtheria, Candidiasis, Vincent angina, Adenovirus, Adeno-associated viruses and Corona virus ${ }^{77}$. Fifty percent of cases are bacterial. The most common causative bacterial agent is $\beta$-haemolytic Streptococci bacteria group A (GABHS). Its infection known clinically as follicular tonsillitis and famously by strep throat. Chronic tonsillitis differs from acute condition by persistent recurrent attacks of acute one and tonsils beside throat tissue severely affected and become as a site of infective organisms.

In general, tonsillitis treatment depends on cause and course of the disease with some common regulations such as all cases should be proceeded by throat swab for laboratory investigation, with consideration of home care and rest for both acute and chronic cases, avoiding contact with risk people, eating soft cold foods, fluids and soups, gargling with salted water and using throat lozenges and mouth washes like glycerol-thymol gargle that has a value to act as a local antiseptic, release the pain and prevent sepsis ${ }^{1}$.

In one hand, first drugs of choice to treat acute bacterial tonsillitis cases are broad spectrum antibiotics such as Penicillin V (benzyl or phenoxymethyl penicillin). It is preferred to use with cases of resistance to other antibiotics. Some antibiotics can aggravate tonsillitis condition like Ampicillin, which causes rash sensitivity especially with infectious mononucleosis patients ${ }^{13}$. Other treatments include NSAID mainly Paracetamol to reduce fever and to relief inflammation.

On the other hand, treatment of chronic cases mainly surgically by tonsillectomy. It is recommended for persistent acute and chronic tonsillitis, and partially indicated for recurrent acute tonsillitis. Urgent absolute indication of tonsillectomy in cases of sleep apnea, respiratory obstruction and in suspicion of malignancy, and relatively indicated for chronic and recurrent acute cases, quinsy and for diphtheria carriers ${ }^{14}$.

Not tonsillitis alone! Many respiratory tract infections constitute major health issue such as flu, bronchitis, influenza and pneumonia which their common symptoms and signs are somehow similar to tonsillitis with slight differences. Physicians and scientists are on challenge to confer safe potent medicines for such cases ${ }^{15,16,78}$. Many of last mentioned cases were treated by antibiotics, which indicate the extent of their usage in treatment of many medical cases.

According to PubMed study related to this article, it revealed that acute upper respiratory tract infections (AURTI) was the most condition for bacterial infectious diseases to prescribe antibiotics, this was by percentage of $49.2 \%$ in Malaysia in 2016. Furthermore, the study disclosed that AURTI were among the top four indications in a given study. This study revealed two findings, firstly, people were mostly undergone an infection of upper respiratory tract among other infectious diseases. Secondly, doctors had prescribed 
antibiotics at high rates. Both matters lead to deduction of importance of AURTI especially tonsillitis, and the urgent need to substitute antibiotics by novel treatment ${ }^{16}$.

\section{Bacterial Resistance to Antibiotics}

Resistant tonsillitis or rather microbial resistance to antibiotic treatments considered as one of problem based learning (PBL) in which the medical researchers need how to deal with clinical problem and how to extract the solution upon related training, this is accomplished within three phases: Problem analysis, Self-directed study and Synthesis and application of newly acquired information ${ }^{17}$.

Development and mass production of antibiotics to treat various bacterial infections was one of the brightest scientific efforts in the last century. They gained their importance and reliability from their effectiveness ${ }^{78}$. Over the past sixty years, clinicians have been depending on them to treat bacterial infections. As a result of their frequent and uncontrolled use, bacteria have developed resistance against them and thus transformed those drugs to less effective agents ${ }^{3,19}$. Recently, those miracle drugs have lost their importance as most of the pathogenic bacteria have become resistant to most or all available antibiotics $^{20,21}$.

Although trials of developing of new classes of antibiotics have continued with time, but it has declined in recent few years. Since 1987, no new classes of antibiotics have been developed even with the help of modern biotechnology ${ }^{22}$. The main problem was that pharmaceutical companies focused only on production of antibiotics from previous known classes ${ }^{23,24}$, at the time that antibiotic resistance problem continued to grow in the absence of real solution.

Prolonged usage of antibiotics encourages bacteria to develop "supergenes". These are mutations that give ability to bacteria to resist almost all available antibiotics ${ }^{23}$. However using the modern biotechnology tools, many experiments suggested the presence of antibiotic resistant genes ${ }^{26,27,28}$. In turn these bacteria become superbugs that are resistant to all or most available antibiotics.

Generally, with the possibilities of using of many biomedicine practical fields, such as biotechnology for sequencing and cloning, scientists could understand many of these pathogenicity mechanisms at a molecular level. For instance, discovering of pathogenicity islands (Pais or PAIs), which are pathogenicity islands that are clustered in 50,000 to 200,000 base pairs at bacterial genome. Many of these Pais are carried on plasmids. They have a property of pathogenicity responsibility ${ }^{29}$. Indeed, it is obvious that bacteria found its way to inherent antibiotic resistance ability with time, the matter that exposes our health to a real danger ${ }^{78}$.

The discovery and public use of penicillin led to the ending of work on dysentery phages in 1944. Despite penicillin having broad spectrum activity against wide range of bacterial strains, typhoid (Salmonella typhi) was not treatable by penicillin. These encouraged scientists to work again on phages as a substitutive solution ${ }^{29}$. Penicillin is the first drug of choice to treat acute and relapsing tonsillitis. Although it is a potent in-vitro antibiotic agent, it exerted inability to eradicate GABHS due to many factors; mainly bacterial interactions, in which beta-lactamaseproducing organisms help to protect GABHS from penicillin and due to broad spectrum killing activity that work on eradication of normal flora which act as a natural defense barrier. Other factors that cause failure of antibiotic therapy include development of bacterial resistance or drug tolerance, mistaken prescription followed improper diagnosis, wrong treatment, patients status and re-infection from carrier ${ }^{30}$.

Reported study revealed the relation between inappropriate prescribing of antibiotics for treatment of acute tonsillitis cases and developing of bacterial resistance at Primary Care Practice (PCP) level, the study disclosed that treatment failure was resulted from inaccurate etiology determining and false prescribing of antibiotics due to low adherence or no adherence to national health guidelines ${ }^{31}$.

Worldwide consensus that finding of safe alternative treatment that replace antibiotics to combat resistant bacterial infections is a top priority, some might ask regarding this priority whether it should started from mild or severe infection? Because that many believe the therapy must begin for invasive cases $^{32}$. For that, extensive trials like developing of medical bacteriophages, phage lytic enzymes or antimicrobial peptides 
(AMP) had been addressed but they failed to bring the ultimate promising solution. An essay listed by Waldetoft \& Brown (2017) focused on study of changing the path of finding the proper antibiotic alternative should begin from research on mild cases depending on two situations, the first, according to their questions, they found that relatively mild infections were responsible for the majority of antibiotic prescriptions than for severe cases, a rationale that led to growing of antibiotic resistance. Second, by focusing upon such these mild infections, this will contribute in resolving of resistance problem, thus increase in success of alternative medicine ${ }^{33,34}$.

Evermore, scientific paper by Stanton in 2013 focused on emergence of antibiotic resistance problem and necessity for discovery of antibiotic alternatives, the study showed the urgent importance to find solution and thus discovery of new and more effective antibacterial agents is primordial ${ }^{59}$.

WHO launched the first antibiotic awareness week in 2015. It warned about losing of antibiotics importance due to bacterial resistance that developed from dependence on well-known classes of antibiotics and their uncontrolled use, and if there is no upcoming solution, our world will face a danger of common infections with no treatment $^{78}$. At the same time, repeated handling trials and mistaken or improper diagnosis and treatment of tonsillitis, brings many dangers to patient health and widen the gap, added to side effects caused by chemically synthetic antibiotic and anti-inflammatory drugs. Altogether worsen our health and subsequently affect life. Hence there is an urgent need to explore potent safe anti-tonsillitis treatment that can be prescribed safely without risks of inappropriate diagnosis to replace old faulted treatment. Therefore herbal medicine seems to be proper solutions that motivate academic researchers and clinicians in the field to substitute.

\section{Bacterial Resistance Impact Dimensions}

Not that treatment effectiveness solely is the consequence of treatment resistance problem, the issue actually extended to many aspects, for instance and not to enclose, fateful impact, economic impact, environmental impact and work efficiency impact.

At present, antibiotic resistant bacteria constitutes a real health care crisis, in which most of bacteria became multi-drug resistant ${ }^{78}$. In 2013, CDC reported that two million of United States (US) people acquire serious infections by resistant strains each year, from those, at least 23,000 die every year. Moreover, 250,000 of people with Clostridium difficile infections require hospital care as a result of uncontrolled use of antibiotics, and about 14,000 of those patients die every year in US $^{35}$. Klevens et al. (2007) listed that the majority of deaths from cases of hospital-acquired infections (HAI) were by antibiotic resistant organisms ${ }^{38}$. For example, in 2006, nearly 50,000 American patients were killed by sepsis and pneumonia (common HAI). These cost their country more than $\$ 8$ billion ${ }^{39}$.

Another study by Filice et al. (2010) found that studies on the cost of antibiotic-resistant infections collected from US health care system ranges from $\$ 21$ billion to $\$ 34$ billion each year, added to more than $\$ 8$ million for additional hospital days, in which the burden of antibiotic resistant infection on each patient cost from \$ 18,588 to $\$ 29,069$ United States Dollar (USD) ${ }^{4}$. Each year the US health care system spent over $\$$ 20 billion per patient ${ }^{37}$. Additionally, the hospital stays for cases suffering antibiotic-resistant infections increased from 6.4 to 12.7 days. It means that those patients are unable to work during this time, thus losing their salaries. The total costs due to these households reaches over $\$ 35$ billion each year.

In addition, CDC also suggested that it is difficult to estimate the exact costs due to many factors, such as: duration of treatment courses whether it is short or long, extended hospital staying period, extra health care uses and additional specialists' visits and advice, and that most of antibiotic-resistant infections need costlier treatments. Some estimates taken from heath care system in US in 2008 revealed that direct health costs on economy reached about $\$ 20$ billion with extra $\$ 35$ billion for lost productivity to society ${ }^{35}$. More Dilemmas upon Synthesized Chemical Antibiotics and Anti-inflammatory Drugs

Common popular use of NSAIDs has lead up to arising and manifestation of adverse drug reactions which become popular everywhere. Many adverse drug reactions and side effects reported on use of NSAIDs such as increased 
risk of gastrointestinal ulcers and bleeds, heart attack and kidney disease, tolerance, gastric lesions, interference with blood coagulation and many others that range from moderate to severe side effects ${ }^{40,41,42}$. Many reports suggested that more side effects appeared with their frequent use, viz., cardiovascular like myocardial infarction and heart stroke ${ }^{43,44}$, erectile dysfunction ${ }^{45}$, inflammatory bowel disease (e.g., Crohn's disease or ulcerative colitis), renal side effects such as interstitial nephritis, nephrotic syndrome, acute kidney injury, acute tubular necrosis and renal papillary necrosis ${ }^{46}$, photosensitivity and allergy.

In fact, due to reported undesired side effects of NSAIDs even at least extent, it is recommendable to apply use of medicinal plants instead ${ }^{47}$. Anywise, chemical side effects not restricted on use of NSAIDs, even antibiotics reported multiple side effects and disadvantages which mentioned on the following table 1 , hence as one of the main reasons, this article necessitated to substitute conventional chemically manufactured treatment by natural medicinal plant $^{48}$.

\section{Traditional Herbal Medicine and Its Advantages as a Promised Solution}

Preeminent medical systems had been used widely in South East Asian Region categorized within folk medical exercises, these include Yoga, Ayurveda, naturopathy, Unani and Tibetan medicine, in which reports reveal that $70-80$ percent of population in this region using phytomedicine. In Malaysia, there are three traditional medicines used widely, these are Traditional Chinese Medicine, Traditional Malay Healers and Traditional Indian Healers. Multiple synonyms of traditional medicine used widely all over the world these include: alternative medicine, complementary medicine, herbal medicine, phytomedicine, non-conventional medicine, indigenous medicine, folk or ethno medicine and natural medicine ${ }^{49}$.

National Center for Complementary and Alternative Medicine (NCCAM) categorized alternative medicine into Whole Medical Systems (such as Ayurveda, herbs and traditional Chinese medicine), Mind-Body Medicine (such as prayer, mental healing and therapies that use creative outlets), Biological Based Practices (like Herbs, vitamins and foods), Manipulative and Body-Based Practices (for instance Chiropractic Medicine and Naturopathy) and Energy Medicine (such as bioelectromagnetic-based therapies and electromagnetic fields $)^{76}$.

One of the oldest medical systems in the Indian subcontinent is Ayurveda. It is experienced since $12^{\text {th }}$ century BC. Ayurveda system constitutes a way of life that look around fulfilment of physical, mental, social and spiritual well-being at the time that phyto-therapy (herbal therapy) constitute a major segment in this system ${ }^{49}$. Herbal remedies have been a principle segment of human health care due to therapeutic effectiveness upon their

Table 1. Main disadvantages of broad spectrum antibiotics

Conventional Antibiotics

Multiple side effects, including intestinal disorders, allergies, and secondary infections (e.g., yeast infections) have been reported, If patient is allergic to antibiotic, treatment is very difficult.

Antibiotics exhibit bactericidal or bacteriostatic effects not only on the cause of bacterial disease, but to all bacteria of our body including normal flora. Thus their non-selective action affects the patient's microbial balance, which may lead to various side effects.

The broad spectrum activity of antibiotics may select for resistant mutants of many pathogenic bacteria species, Resistance to antibiotics is not limited to targeted bacteria.

Some antibiotics are bacteriostatic, i.e., they inhibit the growth of bacteria, rather than killing them (e.g., Chloramphenicol), their use give a chance to bacteria to develop resistance.

They are metabolized and eliminated from the body and do not necessarily concentrate at the site of infection, i.e. they are not specific.

Production is complex and expensive, Developing a new antibiotic (against antibiotic resistant bacteria) is a time consuming process and may take several years to accomplish. 
constituents and classical medicinal plants have been used for thousands of years ago ${ }^{79,50}$. Different human civilizations have their own medicinal plant library, in which some wise people become experienced practitioners and attend to have deep wisdom to deal with domestic plants ${ }^{51}$.

Ancient medical literature of our humanity disclosed that people used to deal with medicinal plants due to their obvious potent effects in both humans and animals and the traditional herbal medicine continued to gain its importance due to its wide therapeutic applications. It earns this prominence from plants' natural chemical composition, i.e. secondary metabolites. Some relative knowledge about many medicinal plants and their mechanism of action enables clinicians to use them as natural remedies ${ }^{52}$. Many antibacterial activity evaluating studies of selected edible plant extracts confirmed their potential actions against MDR bacteria ${ }^{60,61}$.

A study performed by Al-Naggar \& Chen, (2011) focused on nutrition and cancer prevention relationship, the study revealed the importance of human being to depend on natural diet as a result of dietary manipulation is considered in all reports to be the cornerstone of prevention and management efforts of the many mentioned diseases and natural sources of diet and medicines are of great value to natural health equilibrium ${ }^{62}$.

Medicinal plants have powerful experienced efficacy with no encountered side effects, for that higher majority of people tend to depend on them, and about $80 \%$ of worldwide people are on use of these plants for their primary healthcare needs according to $\mathrm{WHO}^{53}$. Furthermore, one of the main factors that increase using of phytotherapy is due to poverty and natural widespread of plants on the earth, this availability reflects the easy ability of patients to get them. Studies performed by Prasad, Rajgopal, Kant \& Badarinath, (1999) and Khan et al., (2014) mentioned some pros of these medicinal plants such as their low cost and ease of use away from complicated health systems and hard transportation facilities that obstruct the way $^{54,55}$.

Nowadays, we believe and trust in natural and organic products, particularly medicines from natural sources, due to desired potent actions and unwanted chemical side effects ${ }^{56}$. In general, medicinal plants have a diverse of chemical components which make them enormous therapies without chemical side effects.

At the end of $19^{\text {th }}$ century, many laboratories tried to begin experiments of investigation on medicinal plant $5^{57}$. Synchronously, human trials to explore new plants are continuous ${ }^{58}$. In fact, many man-made drugs are of plant origin. S. lappa considered as one of the important medicinal plant that played a prominent role in phytotherapy field and widely used by various medical systems mainly ayurveda, but still there is a dearth of ultimate knowledge about medicinal use of S. lappa plant, for which reason its suggestion of use as treatment choice is destined to seek for its lethal effects of roots extract against tonsillitis causing bacteria particularly type A beta haemolytic streptococci in in-vitro model.

On the contrary, phytotherapy faced many problems and challenges and some people thought that it was not proven to give the same effects of synthesized drugs. These thoughts came from two reasons; the first is that related research in many fields was not enough to satisfy the reviewer due to unavailability of specialized phytotherapy centers and laboratories. The second is that the proven works still were not famous and widely known. Add to that, there was a little interaction and collaboration between practitioners who worked on understanding of botany and those who worked on therapeutic uses of plants.

\section{Why Saussurea Lappa?}

Reviewed literature about S. Iappa disclosed that the plant possessed potent antibacterial and anti-oxidant activities. Antimicrobial activity of $S$. lappa resulted from its composition, particularly the hydroxyl $\left(\mathrm{OH}^{-}\right)$group in its structure which prevents bacterial growth by denaturation process, thus increasing cellular membrane permeability ${ }^{80}$, which in turn cause rupture of cell membrane and death of bacteria ${ }^{63}$.

Traditionally, S. lappa used by old Korean physicians to treat peptic ulcer, asthma, cough, pharyngitis, it is used as anti-inflammatory, anti-septic and anti-tumor agent too ${ }^{64}$. S. lappa considered as one of the most widely used ethno pharmacological plant in Shopian forest of Kashmir ${ }^{7}$. S. lappa family is widely spread in India. It is useful in treatment of asthma, cough 
and peptic ulcer according to ayurveda clinicians. Additionally, from the Indian literature, there are many drugs described by ayurveda classics which used in treatment of Tundikeri (disease that has same signs and symptoms of tonsillitis) ${ }^{66}$.

From the Indian literature on treatment trials regarding tonsillitis, they experienced many management methods, such as using of oral medications added to local application of treatments like Gandusha and Kavala, and last treatment of choice is surgery ${ }^{66}$. But according to ayurveda, combination of oral herbal drugs with local application of treatments can be useful even in cases of recurrent tonsillitis before ending fate of surgery.

Basically, roots have chemical composition of essential oils (1\%), alkaloids $(0.05 \%)$ and saussarine. these substances have many beneficial medical uses without side effects. For example, essential oil content has expectorant, antispasmodic and diuretic effects. Other ingredients include resinoids (6\%), inulin (18\%), saussurea lactones (20-25\%), fixed oils and minor content of tannin and sugars. Even more, constituents of roots vary from Indian plant and from other countries sources. One of the amazing characteristics of essential oils is their powerful action against bacteria. A valuable overview of chemo-profile of S. lappa plant disclosed the main pharmacological constituents were cynaropicrin, saussureamines A \& B, costunolide and dehydrocostus lactone.

Phytochemical studies of S. Iappa revealed the presence of terpenes: monoterpenes like anethole, thymol and camphor ${ }^{67,68}$, sequiterpenes: especially sequiterpene lactones from plant roots essential oils ${ }^{69}$, flavonoids: such as luteolin, rutin and apigenin ${ }^{70}$, phytosterols: as lappasterol, anthraquinone compounds and many others. A chemo-profile of S. lappa was mentioned by details in reviews by Singh, Chahal \& Singla in $2017^{71,72}$.

In spite of potent bioactivities of folk plant medicines in facing of many diseases, total comprehensive profile of plants active ingredients have not been clearly mentioned because of their complicated chemical composition. However, part of chemical form that is responsible to induce anti-inflammatory properties have been suggested and reported by many researchers, these compounds include alkaloids, flavonoids (the major anti-inflammatory agent), ligans, peptides, polyphenols, polysaccharides and saponins $^{73,74}$.

Many several in-vitro and in-vivo test models were done by related experts to investigate pharmacological properties of the S. lappa plant. In general, they deduced many of its activities such as anti-ulcer, anti-tumor, immunomodulatory, anti-inflammatory, hepatoprotective, antifeedant, antibronchitis, hypolipidaemic, hypoglyceamic, anti-parasitic, and central nervous system (CNS) depressant activities and effects ${ }^{72}$. All of these explained, discussed and reported by related researchers in the field. A scientific review on $S$. lappa done by Pandey et al., (2007) brings many details of these actions organized accordingly $y^{72}$.

They knocked through and reported the anti-inflammatory properties of ethanol $\&$ methanol extracts of roots of $S$. lappa. For instance, methanol extract exhibited an inhibition effect of Cytokine Induced Neutrophil Chemotactic factor (CINC) initiation and suppresses nitric oxide synthase enzyme ${ }^{75}$. Additionally, this extract exerts strong inhibitory effect on production of Tumor Necrosis Factor-alpha (TNF- $\alpha$ ) and pro inflammatory cytokines. Yu et al., (2007) reported the inhibitory effect of ethanol extract of S. lappa on Streptococcus mutans which exerted a significant inhibitory action and prevent the bacterial growth and acid production at concentration of 0.5-4.0 $\mathrm{mg} / \mathrm{ml}$. Even at this concentration, ethanol extract exhibits anti-adherent activity on bacteria and inhibits formation of water-insoluble glucan ${ }^{65}$. Yu et al., (2007) listed some activities of S. lappa on oral diseases, in which it manifests considerable therapeutic effects on dental caries, halitosis and periodontal diseases that are related to infection by S. mutans ${ }^{65}$.

Different plants are varying apparently in distribution of phytochemicals and active ingredients in their different parts of plant accordingly ${ }^{36}$. Many preceding ayurveda physicians informed that $S$. lappa roots are the main part of plant ${ }^{25,18}$. This plant used broadly by locals for different purposes especially for respiratory tract illness. S. lappa roots are easy to handle (does not leak like a fluid), safe (not harmful or hazardous matter), cheaper and can be stored easily for future use. 
In nutshell, many phytotherapy practitioners performed experiments suggested the potent positive effects of ayurveda plants in general against tonsillitis. These plants possess number of brilliant properties (such as their anti-inflammatory, anti-viral, anti-pyretic, antioxidant and anti-pain activities) that enable them to act as a broad spectrum drugs. These effects help together to treat such diseases with desired efficacy and safety.

\section{DISCUSSION}

Tonsillitis is disquieting disease toward its patients, its recurrent attacks disturbing life and distressing patients. Many cases around the world suffering the pain of tonsillitis which ranges from mild to severe pain in many cases, thus majority of cases tend to consume sedatives such as NSAIDs regularly with prescribed chemical antibiotics, in which both accompanied by their hazardous side effects. At the same time, fail of tonsillitis treatment that resulted over developed bacterial resistance to available antibiotics, enhance the reason to find a promised efficient solution assumed by testing of natural potent treatments that experienced without side effects

Conventional antibiotics endangers our normal flora, subsequently our health as mentioned. These jeopardies imperil livings on the planet as well as environment. Awareness of $\mathrm{WHO}$ and related organizations belled out the upcoming real danger of resistance problem and losing of antibiotics as antibacterial treatments, gives meaning to factual extent of impact and bring responsibility to find alternative safe drug. Actually, we need to decrease depending on chemical antibiotics gradually synchronized with offering and increasing use of safe substitutive medicines.

Meanwhile tonsillitis can present as viral or bacterial infection, simply looking and inspection at tonsils for diagnosis does not reveal the cause. Thus, prescribing antibiotics to wrongviral affected patient as happen by many doctors is a medical mistake, for that there is need to treat by right choice drug, that must be active and potent against both causatives and preferable to hold local anti-septic effects, added to its guaranteed safety and its ease of prescribe and use by everyone as over the counter (OTC) drug. This gives a rationale that many phytotherapy plants including S. lappa hold multi effective activities (like to be antibacterial, ant-viral and anti-septic) at the same time.

Indeed, ancient use of S. lappa by rural communities for a long time indicates that there are beneficial roles with no historical aforesaid side effects associated with its use with taken in mind's eye long term its use. Thereafter, according to results from researches and previous studies on S. lappa potent chemical composition, enhanced by evidences from literature review over a long time which informed that this plant possess a wide potent anti-microbial, anti-inflammatory and antiseptic bounce. Altogether, leads to a rationale that S. lappa can be used as an effective anti-tonsillitis treatment.

Exceedingly presentation of the extent of antibiotic bacterial resistance problem and the importance of herbal medicines as a prospective choice of antibacterial treatment, through review of previous and current literature as well as practical investigatory lab work will disclose more facts about advantages and disadvantages of both treatments when compared to each other.

\section{CONCLUSION AND RECOMMENDATION}

In conclusion, the world is moving towards losing of antibiotics, those marvel drugs that lived for decades to fight bacteria that were responsible to cause many diseases. Tonsillitis is one of those infections that have wide presence throughout the world. Previously and currently, it was treated by broad spectrum antibiotics. Researchers in related fields, due to developed bacterial resistance and ineffective treatment seek for alternative safe treatments and many believe that solution lay in depending on herbal medicines; they depended on rationale of their safety and potency. This paper focus on future need of evaluating (by lab work) of S. lappa roots extract as an effective safe herbal remedy for acute tonsillitis cases whose infected mainly by bacteria.

To help in elimination of antibiotics crisis and to replace them by safe treatments we need to evaluate specific natural herbal treatment (S. lappa) whether it is effective and safe or not toward particular case (tonsillitis bacteria), there is an urgent need to initiate lab experiment studies for such testing. The prospective collected 
information and results supposed to contribute in the richness of herbal pharmacy medicines and biomedicine libraries as well as adding knowledge for new researchers in the field and to open a new door for natural therapy for such cases to overcome developed antibiotic resistance problem.

Evaluation of anti-bacterial and antiinflammatory activities of S. lappa roots extract against tonsillitis bacteria then determination of specific concentration for extraction which presents the peak activity, this will help in affording of potent treatment for tonsillitis cases, and importantly to decrease depending on antibiotics at least at tonsillitis level, and will share in diminishing bacterial resistance issue. Testing and evaluation of toxic effects of the plant extract will help in offering safe drug easy to prescribe (or selfprescribed) to all types of tonsillitis cases without risk of side effects of existing prescribed drugs and without risk of wrong diagnosis or prescribing.

Moreover, S. Iappa owns antiseptic effects beside its proposed anti-microbial and antiinflammatory effects. Hence, due to all previously mentioned justifications, this article attempts to focus on S. lappa as an important potent medicinal plant to help in relieving condition of acute tonsillitis. It is recommended to focus on testing of different ethanol extract concentrations from $S$. lappa roots against $\beta$-hemolytic streptococci type-A bacteria by in-vitro laboratory experiment to evaluate the effectiveness. Medically, using this herb for treatment of acute tonsillitis, this supposed to add extra prospective medical effects added to treatment course by collecting of antibacterial, anti-inflammatory and anti-septic effects in one agent. It will be incredible if the plant exerts an anti-viral and anti-fungal effects too in the future.

\section{ACKNOWLEDGEMENTS}

None

\section{CONFLICT OF INTEREST}

The authors declares that there is no conflict of interest.

\section{REFERENCES}

1. Kingsnorth, A., Bennet, D. H., Russell, R. C. G., Williams, N. S., \& Bulstrode, C. J. K. Bailey and Love's short practice of surgery. Russel RCG, Williams NS and Bulstrode CJK, 2000, 679-682.

2. Bull, T. R., \& Almeyda, J. S. Color atlas of ENT diagnosis. Annals of the Royal College of Surgeons of England, 2011; 93(2), 179.

3. Fischetti, V. A. Bacteriophage lysins as effective antibacterials. Curr. Opin. Microbiol., 2008; 11(5), 393-400.

4. Filice, G. A., Nyman, J. A., Lexau, C., Lees, C. H., Bockstedt, L. A., Como-Sabetti, K., \& Lynfield, R. Excess costs and utilization associated with methicillin resistance for patients with $S$. aureus infection. Infect Control Hosp Epidemiol, 2010; 31(04), 365-373.

5. Wanzala, W., Zessin, K. H., Kyule, N. M., Baumann, M. P. O., Mathias, E., \& Hassanali, A. Ethnoveterinary medicine: a critical review of its evolution, perception, understanding and the way forward. Livestock Research for Rural Development, 2005; 17(11), 1-31.

6. Bagul, M. S., Srinivasa, H., Kanaki, N. S., \& Rajani, M. Antiinflammatory activity of two Ayurvedic formulations containing guggul. Indian J Pharmacol, 2005; 37(6), 399.

7. Jan, R. A., \& Khare, N. Ethnopharmacological uses of plants among Tribal and Rural Folks of Shopian forest area of Kashmir. Internat J Sci Res, 2015; 4, 232-234.

8. Savic, M., \& rdal, C. A Grant Framework as a Push Incentive to Stimulate Research and Development of New Antibiotics. J Law Med Ethics, 2018; 46(1_suppl), 9-24.

9. Phanse, M. A., Patil, M. J., Abbulu, K., Chaudhari, P. D., \& Patel, B. In-vivo and in-vitro screening of medicinal plants for their anti-inflammatory activity: An overview, 2012.

10. Bhargava, K. B., Bhargava, S. K., \& Shah, T. M. Sinusitis in A short text book of ENT disease. Usha publication, 2002, 186-189.

11. Dubai, S. A. R. A., Ganasegeran, K., Alabsi, A. M., Alshagga, M. A., \& Ali, R. S. Awareness and knowledge of oral cancer among university students in Malaysia. Asian Pac. J. Cancer Prev., 2012; 13(1), 165-168.

12. Perry, M., \& Whyte, A. Immunology of the tonsils. Immunol Today, 1998; 19(9), 414-421.

13. Coon, J. T., \& Ernst, E. Andrographis paniculata in the treatment of upper respiratory tract infections: a systematic review of safety and efficacy. Planta medica, 2004; 70(04), 293-298.

14. Atta, A. H., \& Alkofahi, A. Anti-nociceptive and antiinflammatory effects of some Jordanian medicinal plant extracts. J Ethnopharmacol, 1998; 60(2), 117124.

15. Jaric, S., Popovic, Z., Mavukanovic-Jociт, M., Djurdjevic, L., Mijatovic, M., Karadzic, B., \& Pavlovic, P. An ethnobotanical study on the usage of wild medicinal herbs from Kopaonik Mountain (Central Serbia). J Ethnopharmacol, 2007; 111(1), 160-175.

Ab Rahman, N., Teng, C. L., \& Sivasampu, S. Antibiotic prescribing in public and private practice: a crosssectional study in primary care clinics in Malaysia. BMC Infectious diseases, 2016; 16(1), 208.

17. Al-Naggar, R. A., \& Bobryshev, Y. V. Acceptance of problem based learning among medical 
students. Journal of Community Medicine and Health Education, 2012; 2(5).

18. Dhar, M. L., Dhar, M. M., Dhawan, B. N., Mehrotra, B. N., \& Ray, C. Screening of Indian plants for biological activity: I. Indian journal of experimental biology, 1968; 6(4), 232-247.

19. Parisien, A., Allain, B., Zhang, J., Mandeville, R., \& Lan, C. Q. Novel alternatives to antibiotics: bacteri-ophages, bacterial cell wall hydrolases, and antimicrobial peptides. J Appl Microbiol, 2008; 104(1), 1-13.

20. Livermore, D. M. The need for new antibiotics. Clinical Microbiology and Infection, 2004; 10(s4), 1-9.

21. Fischetti, V. A. Using phage lytic enzymes to control pathogenic bacteria. BMC oral health, 2006; 6(1), 1.

22. Theuretzbacher, U. Recent FDA antibiotic approvals: good news and bad news. The center for disease dynamics, economics \& policy, 2015, 12.

23. Carlton, R. M. Phage therapy: past history and future prospects. Archivum Immuno-logiae Et Therapiae Experimentalis-English Edition, 1999; 47, 267-274.

24. Sulakvelidze, A., Alavidze, Z., \& Morris, J.G. Bacteriophage therapy. Antimicrob. Agents Chemother., 2001; 45(3), 649-659.

25. Chopra, R. N., Nayar, S. L., \& Chopra, I. C. Glossary of Indian medicinal plants. New Delhi: C SIR, 1956.

26. Andersson, D. I., \& Hughes, D. Persistence of antibiotic resistance in bacterial populations. FEMS microbiology reviews, 2011; 35(5), 901-911.

27. Salyers, A. A., \& Amabile-Cuevas, C. F. Why are antibiotic resistance genes so resistant to elimination? Antimicrob. Agents Chemother., 1997; 41(11), 2321.

28. Stanton, T. B., \& Humphrey, S. B. The persistence of antibiotic resistance: evaluation of a probiotic approach using antibiotic-sensitive Megasphaera elsdenii strains to prevent colonization of swine by antibiotic-resistant strains. Appl. Environ. Microbiol., AEM-00647, 2011.

29. Kutter, E. Practical Handbook of Microbiology Bacteriophages as Natural, Self-Replicating Antimicrobials, Second Edition, CRC press, edited by Emanuel Goldman and Lorrence H. Green, 2008, print ISBN: 978-0-8493-9365-5, eBook ISBN: 978-1-42000933-0.

30. Brook, I. Anaerobic infections in childhood. Boston: GK Hall. Retrieved from www.tonsilitisunderstood. blogspot.com/p/cuses-of-penicillin-failure-in.html, 1983.

31. Nejashmikj, V. R., Stojkovska, S., Topuzovska, I. K., \& Stavrikj, K. Evidence Based Practice in Using Antibiotics for Acute Tonsillitis in Primary Care Practice. Prilozi, 2017; 38(2), 63-68.

32. Czaplewski, L., Bax, R., Clokie, M., Dawson, M., Fairhead, H., Fischetti, V. A., ... \& Henderson, I. R. Alternatives to antibiotics-a pipeline portfolio review. The Lancet infectious diseases, 2016; 16(2), 239-251.

33. Waldetoft, K. W., \& Brown, S. P. Alternative therapeutics for self-limiting infections-an indirect approach to the antibiotic resistance challenge. PLoS biology, 2017; 15(12), e2003533.

34. Allen, R. C., Popat, R., Diggle, S. P., \& Brown, S. P. Targeting virulence: can we make evolution-proof drugs? Nat. Rev. Microbiol., 2014; 12(4), 300.
35. Centers for Disease Control and Prevention [CDC], Antibiotic Resistance Threats in the United States, 2013. https://www.cdc.gov/drugresistance/threatreport-2013/.

36. Kagbo, H. D., \& Obinna, V. C. Investigations of methanolic leaf extract of Costus lucanuscianus on gestation in albino rats. IJPCBS; 2018; 8(1), 14-17.

37. Haddix, A. C., Teutsch, S. M., \& Corso, P. S. Prevention effectiveness: a guide to decision analysis and economic evaluation. Oxford University Press. 2003, 345-357.

38. Klevens, R. M., Edwards, J. R., Richards Jr, C. L., Horan, T. C., Gaynes, R. P., Pollock, D. A., \& Cardo, D. $M$. Estimating health care-associated infections and deaths in US hospitals, 2002. Public health reports, 2007, 160-166.

39. Eber, M. R., Laxminarayan, R., Perencevich, E. N., \& Malani, A. Clinical and economic outcomes attributable to health care-associated sepsis and pneumonia. Arch. Intern. Med., 2010; 170(4), 347-353.

40. Bally, M., Dendukuri, N., Rich, B., Nadeau, L., HelinSalmivaara, A., Garbe, E., \& Brophy, J. M. Risk of acute myocardial infarction with NSAIDs in real world use: bayesian meta-analysis of individual patient data. bmj, 2017, 357, 1909.

41. Lanas, A., \& Chan, F. K. Peptic ulcer disease. The Lancet, 2017; 390(10094), 613-624.

42. Winter, C. A. Nonsteroid anti-inflammatory therapy. II. Research on new anti-inflammatory compounds. Gaceta medica de Mexico, 1967; 97(5), 543.

43. Kearney, P. M., Baigent, C., Godwin, J., Halls, H., Emberson, J. R., \& Patrono, C. Do selective cyclo-oxygenase-2 inhibitors and traditional nonsteroidal anti-inflam-matory drugs increase the risk of atherothrombosis? Meta-analysis of randomised trials. Bmj, 2006; 332(7553), 1302-1308.

44. Trelle, S., Reichenbach, S., Wandel, S., Hildebrand, P., Tschannen, B., Villiger, P. M., ... \& J ni, P. Cardiovascular safety of non-steroidal anti-inflammatory drugs: network meta-analysis. Bmj, 2011; 342, c7086.

45. Shiri, R., Koskimnki, J., Hnkkinen, J., Tammela, T. L. J., Auvinen, A., \& Hakama, M. Effect of nonsteroidal anti-inflammatory drug use on the incidence of erectile dysfunction. The Journal of urology, 2006; 175(5), 1812-1816.

46. Rossi, S. Australian medicines handbook. Adelaide: Australian Medicines Handbook, 2006, 2-3.

47. Vasudevan, M., Gunnam, K. K., \& Parle, M. Antinociceptive and anti-inflammatory effects of Thespesia populnea bark extract. Journal of ethnopharmacology, 2007; 109(2), 264-270.

48. Chhibber, S., \& Kumari, S. Application of Therapeutic Phages in Medicine. INTECH Open Access Publisher, 2012.

49. Al-Naggar, R. A., Bobryshev, Y. V., Abdulghani, M. A. M. M., Rammohan, S., \& Al-Jashamy, K. Knowledge and perceptions of cancer and cancer prevention among Malaysian traditional healers: a qualitative study. Asian Pacific J Cancer Prevent, 2012; 13(8), 3841-3850.

50. Abu-Rabia, A. Urinary diseases and ethnobotany among pastoral nomads in the Middle East. Journal 
of Ethnobiology and Ethnomedicine, 2005; 1(1), 4.

51. Abbasi, A. M., Khan, S. M., Ahmad, M., Khan, M. A., Quave, C. L., \& Pieroni, A. Botanical ethnoveterinary therapies in three districts of the Lesser Himalayas of Pakistan. J Ethnobiol and Ethnomed, 2013; 9(1), 84.

52. Ratheesh, M., \& Helen, A. Anti-inflammatory activity of Ruta graveolens Linn on carrageenan induced paw edema in wistar male rats. African journal of Biotechnology, 2007; 6(10).

53. Shah, G. M., Abbasi, A. M., Khan, N., Guo, X., Khan, M. A., Hussain, M., ... \& Tahir, A. A. Traditional uses of medicinal plants against malarial disease by the tribal communities of Lesser Himalayas-Pakistan. Journal of ethnopharmacology, 2014; 155(1), 450-462.

54. Prasad, V. K., Rajgopal, T., Kant, Y., \& Badarinath, K. V. S. Food plants of Konda Reddis of Rampa Agency, East Godavari district, Andhra Pradesh-a case study. Ethnobotany, 1999; 11, 92-96.

55. Khan, N., Abbasi, A. M., Dastagir, G., Nazir, A., Shah, G. M., Shah, M. M., \& Shah, M. H. Ethnobotanical and antimicrobial study of some selected medicinal plants used in Khyber Pakhtunkhwa (KPK) as a potential source to cure infectious diseases. BMC Complement and Alternat Med, 2014; 14(1), 122.

56. Ameh, S. J., Obodozie, O. O., Afolabi, E. K., Oyedele, E. O., Ache, T. A., Onanuga, C. E., \& Inyang, U. S. Some basic requirements for preparing an antisickling herbal medicine-NIPRISAN. African Journal of Pharmacy and Pharmacology, 2009; 3(5), 259-264.

57. Zaika, L. L. Spices and herbs: their antimicrobial activity and its determi-nation. Journal of Food Safety, 1988; 9(2), 97-118.

58. Torres, M. P., Rachagani, S., Purohit, V., Pandey, P., Joshi, S., Moore, E. D., ... \& Batra, S. K. Graviola: a novel promising natural-derived drug that inhibits tumorigenicity and metastasis of pancreatic cancer cells in vitro and in vivo through altering cell metabolism. Cancer letters, 2012; 323(1), 29-40.

59. Stanton, T. B. A call for antibiotic alternatives research. Trends in Microbiology, 2013; 21(3), 111-113.

60. Djeussi, D. E., Noumedem, J. A., Seukep, J. A., Fankam, A. G., Voukeng, I. K., Tankeo, S. B. \& Kuete, V. Antibacterial activities of selected edible plants extracts against multidrug-resistant Gram-negative bacteria. BMC complementary and alternative medicine, 2013; 13(1), 164.

61. Witkowska, A. M., Hickey, D. K., Alonso-Gomez, M., \& Wilkinson, M. Evaluation of antimicrobial activities of commercial herb and spice extracts against selected food-borne bacteria. J Food Res, 2013; 2(4), 37.

62. Al-Naggar, R. A., \& Chen, R. Nutrition and cancer prevention: knowledge, attitudes and practices among young Malaysians. Asian Pac J Cancer Prev, 2011; 12(3), 691-694.

63. Lunavath, V., \& Mamidala, E. Human immunodeficiency virus (HIV-1) reverse transcriptase inhibitory activity of Eclipta alba (L) leaves extracts, 2012.

64. Yuan, H., Ma, Q., Ye, L., \& Piao, G. The traditional medicine and modern medicine from natural products. Molecules, 2016; 21(5), 559.

65. Yu, H. H., Lee, J. S., Lee, K. H., Kim, K. Y., \& You, Y. O. Saussurea lappa inhibits the growth, acid production, adhesion, and water-insoluble glucan synthesis of Streptococcus mutans. J Ethno-pharmacol, 2007; 111(2), 413-417.

66. Nayak, V., Jadhav, V., \& Sajjanshetty, M. R. Traditional medicine in the management of Recurrent TonsillitisAn Ayurvedic Perspective. J Ayurveda and Integrated Medical Sciences, 2018; 2(6), 98-106.

67. Chang, K. M., \& Kim, G. H. Comparison of volatile aroma components from Saussurea lappa CB Clarke root oils. Preventive Nutrition and Food Science, 2008; 13(2), 128-133.

68. Gwari, G., Bhandari, U., Andola, H. C., Lohani, H., \& Chauhan, N. Volatile constituents of Saussurea costus roots cultivated in Uttarakhand Himalayas, India. Pharmacognosy research, 2013; 5(3), 179.

69. Liu, Z. L., He, Q., Chu, S. S., Wang, C. F., Du, S. S., \& Deng, Z. W. Essential oil composition and larvicidal activity of Saussurea lappa roots against the mosquito Aedes albopictus (Diptera: Culicidae). Parasitology research, 2012; 110(6), 2125-2130.

70. Alaagib, R. M. O., \& Ayoub, S. M. H. On the chemical composition and antibacterial activity of Saussurea lappa (Asteraceae). The Pharma Innovation, 2016; 4(2, Part C)

71. Singh, R., Chahal, K. K., \& Singla, N. Chemical composition and pharmacological activities of Saussurea lappa: A review. J Pharmac and Phytochem, 2017; 6(4), 1298-1308.

72. Pandey, M. M., Rastogi, S., \& Rawat, A. K. S. Saussurea costus: botanical, chemical and pharmacological review of an ayurvedic medicinal plant. Journal of ethno-pharmacology, 2007; 110(3), 379-390.

73. Sparg, S., Light, M. E., \& Van Staden, J. Biological activities and distribution of plant saponins. Journal of ethno-pharmacology, 2004; 94(2-3), 219-243.

74. Wen, D., Liu, Y., Li, W., \& Liu, H. Separation methods for antibacterial and antirheu-matism agents in plant medicines. Journal of Chromatography B, 2004; 812(12), 101-117.

75. Lee, G. I., Ha, J. Y., Min, K. R., Nakagawa, H., Tsurufuji, S., Chang, I. M., \& Kim, Y. Inhibitory effects of oriental herbal medicines on IL-8 induction in lipopolysaccharide-activated rat macrophages. Planta Medica, 1995; 61(01), 26-30.

76. Al-Naggar, R. A., Bobryshev, Y. V., Abdulghani, M., Rammohan, S., Osman, M. T., \& Kadir, S. Y. A. Complementary/alternative medicine use among cancer patients in Malaysia. World J. Med Sci., 2013; 8(2), 157-164.

77. El-Mishad Abla M. Manual of Practical Microbiology. Third Edition. Cairo: Kalyoub-Egypt 1997, 149-157.

78. Mindez-Vilas, A. (Ed.). The Battle Against Microbial Pathogens: Basic Science, Technological Advances and Educational Programs. N Microbiology Series, Formatex Research Center, Spain, 2015.

79. Duraipandiyan, V., \& Ignacimuthu, S. Antibacterial and antifungal activity of $C$. fistula L.: An ethnomedicinal plant. J Ethnopharmacology, 2007; 112(3), 590-594.

80. Rastogi, R. P., \& Mehrotra, B. N. Glossary of Indian medicinal plants. National Institute of science communication, New Delhi, India, 2002, 20-25. 